\title{
Down House as a Darwin Memorial.
}

M R. GEORGE BUCKSTON BROWNE, fellow of the Royal College of Surgeons of England and of the Society of Antiquaries, London, having acquired Darwin's home, Down ${ }^{1}$. House, in the County of Kent, from Prof. C. G. Darwin, grandson of the naturalist, has transferred its possession to the British Association under the most liberal conditions, and with an endowment amply sufficient for its maintenance and preservation for all time. The Association have now issued a full description of the house, and from it the subjoined particulars have been extracted.

At present Down House serves as a private school. When the tenant's lease falls in or is acquired, Mr. Buckston Browne desires that the property be regarded as a gift to the nation and opened to visitors every day of the week between the hours of 10 and 6 , without charge. He also desires that the Association should use Down House and grounds for the benefit of science. The donor has also suggested that certain of the rooms-particularly the old 'study,' in which the " Origin of Species " was written, should be furnished, as near as may be possible, as they were when Darwin lived in them. He has already taken steps to secure this end, and has obtained the willing co-operation and greatest assistance from various members of the Darwin family. Indeed, without the generous co-operation of the Darwin family the transfer of ownership could not have been effected. The late Mrs. Litchfield, the third daughter of Charles Darwin, bequeathed for Down House her father's study chair and letter-weighing machine. Mr. Buckston Browne has commissioned the Hon. John Collier to paint replicas of his wellknown portraits of Darwin and of Huxley to be hung at Down House, commissions already completed.

It is hoped that the shelves of the old study may be filled with all editions of Darwin's works; and that Down House may become a Darwiniana where students will have an opportunity of consulting all orjginal documents concerning Darwin and his writings. Such an end can be attained only if the British Association succeeds in enlisting the sympathetic co-operation of all who may be the fortunate owners of articles which were in the possession of Darwin or were associated with his life.

It may not be amiss to recount some of the circum. stances which led up to the appeal for the preservation of Darwin's home. Some years before his death, the late Sir Arthur Shipley, Master of Christ's College, Cambridge, where Darwin was an undergraduate, wrote to a member of the British Association as follows: "It seems to me that Down House ought to be a national possession. Do you know of any means by which this can be brought about?" On the eve of the Leeds meeting of the British Association, on Aug. 31 of last year, the Council of the Association considered this matter and empowered the then president (Sir Arthur Keith) to make a public appeal at the close of his presidential

'On the Ordnance Survey maps the spelling is Downe, but as Darwin
always wrote Down without an 'e,' the latter spelling has been adopted. No. 3071, VoL. 122] address, with the happy result which all now know. It was with as much surprise as satisfaction that Sir Arthur Keith learned that the man who answered the call was a fellow of his own College. Indeed, he knew Mr. Buckston Browne as a generous benefactor to that College and to the Harveian Society, but was unaware of his love for Darwin and for Down. It was later that he learned that Darwin's friend Huxley had long ago exerted an abiding influence on the donor of Down.

Darwin was born at Shrewsbury on Feb. 12, 1809; Down House was purchased for him by his father, Dr. Darwin, and he took up his residence there on Sept. 14, 1842. Darwin was then in his thirtyfourth year ; three years previously he had married his cousin, Emma Wedgwood. His two eldest children, William and Anne, were born in London; the third, Mary, was born and died just after arrival at Down. Then followed in 1843 Henrietta, who became Mrs. Litchfield; in 1845, George, who became Sir George Darwin, and whose son, Prof. C. G. Darwin, succeeded to the ownership of Down and is the fifth of a succession of father and son who have been elected fellows of the Royal Society -a unique record ; in 1847 Elizabeth was born; in the following year Francis, who became Sir Francis Darwin-a distinguished botanist and president of the British Association. Leonard followed in 1850-Major Leonard Darwin, scientific worker, philanthropist, and the founder and still active supporter of the Eugenics Society. Then came Horace, now Sir Horace Darwin, happily, still alive; and last, number 10, Charles Waring Darwin, who died in childhood. Down was the home of a large and happy family, perhaps the most gifted family ever born in England. There the great naturalist died on April 19, 1882.

In that period Darwin made his first draft of the "Origin of Species" (1842); he wrote his researches on the zoology of the Beagle, on "Structure and Distribution of Coral Reefs," and prepared a new edition of his "Journal of a Naturalist." Before he settled down to work at barnacles, to which he gave seven years (1847-54), he prepared his papers on volcanic islands and on the geology of South America. Preparations for the "Origin of Species," which did not receive its final form until 1858-59, went on continuously from 1842 onwards. Then followed his inquiries into "Fertilisations of Orchids" (1862), "Variations of Animals and Plants under Domestication " (1868), "Descent of Man" (1871), "Expression of the Emotions" (1872), "Movements and Habits of Climbing Plants" (1876); "Insectivorous Plants" appeared in the same year ; "Cross-" and SelfFertilisation " in 1876, and his last work of all, one which was begun soon after he settled at Down, "The Formation of Vegetable Mould through the Action of Worms."

No single home in the world can show such a record. Truly, from Down, Charles Darwin shook the world and gave human thought an impress which will endure for all time. 